\title{
COMPLEX INTEGRATED METHOD OF IMPROVEMENT OF SPORTS BALLROOM DANCE PERFORMANCE
}

Omelyanenko V.I.

Mykolaiv Higher Sportsmanship School

\begin{abstract}
Annotation. Purpose: to elaborate complex integrated method of psychological influence upon sport ballroom dancers for their quick response to assumed mistakes by executing other steps in training mode in place of given compositions. Material: 20 senior sport ballroom dancers: 10 - experimental group, 10 - control group. At the I stage dancers for participation in the experimental group with regard to their hypnosis ability for facilitation teaching dynamic meditation were selected. Sportsmen with the $2^{\text {nd }}-3^{\text {rd }}$ stage of hypnosis were enrolled to the experimental group. At the II stage the experimental group was trained in the method of dynamic meditation. For this, the static meditation was performed first, after this the test persons opened their eyes and without leaving the achieved result with help of the static state of meditation, practiced in dynamic meditation. At the III stage training in sports ballroom dances with introduction new steps changing the composition program sequence to composition was held. The coach evaluated response of the test persons in the state of the dynamic meditation. Results: at the II stage of the research on training in dynamic meditation the dancers of the experimental group needed 3-7 repetitions. At the III stage of the research 8 test persons had trained to response adequately to changes in the compositions within 10-15 repetitions. In the control group if a partner changed steps during performance of the composition it led to stop of the dancing couple. For 8 test persons in the experimental group steps replacement didn't affect adversely the quality of the dance. The senior group of dancers studied new steps with great difficulty, their motion stereotype was formed badly, they preferred to dance compositions trained earlier. The seniors having insufficient technical background ( 2 persons) showed low abilities, they had bad memory, they spent 3 months for mastering new compositions. Conclusions: The methods elaborated by us providing for inclusion in the training process stand-alone dance steps in place of compensation steps, provided development of the dancers' ability to respond quickly to assumed mistakes during dance performance. Mastering dynamic meditation depended on typological features of the nervous system: the higher hypnosis ability degree the better mastering. Women-partners of the experimental group who had high hypnosis ability degree and mastered dynamic meditation could quickly adequately response to the rapid changes in the composition performed by dance partner during dance. Consideration of possible errors trains a woman-partner's ability to switch timely from one step to another. Using this method, improvement of professional skills of dancers accelerates greatly.
\end{abstract}

Keywords: dance sport, mistake correction, dynamic meditation, training.

\section{Introduction}

Sport ball dances have become still more popular among population. There are different methodological approaches to dances' training. If in some kinds of sports only final result is important, while technique, the basis of this result, does not render any influence on spectators, aesthetic component of sport ball dances is od first importance and considered by referees.

Free change of any figures in composition by any reason results in failure in movements of dancing pair. Mistakes in dances are periodically made by all dancers, but not all pairs are able to hide them from spectators.

Probability of errors can be calculated basing of theory of probabilities. Probability of correct fulfillment increases owing to numerous repetitions of compositions for working out of movements' stereotype.

The method of stereotypes' training and correction of sportsmen's mistakes with the help of hypnosis is wellknown. The only difficulty of this method is that a hypnologist shall participate in training [7].

Peculiar trainings are required in any profession; for example actors' training by K.S. Stanislavskiy trains ability for quick emotional re-switching from one state to other [8].

Analyzing dynamic meditation in martial arts it is necessary to pay attention to the fact that it permits to momentarily use required techniques from accumulated sport arsenal of a sportsman at sub-conscious level in certain situation [1]. Quick responding to changes in combat is the basis of victory. Variable conditions of fight do not permit to make compositions with strict sequence of techniques. As far as sport ball dances concern, dancing pairs make variations and compositions in order to work out stereotype movements [2-4, 9, 10-15].

Dynamic meditation has many positive sides, such as method of dynamic meditation's integration with "conscious breathing" of Buddhists, which ensures improvement of psycho-emotional state, increases quality of dance's fulfillment [6].

Method of effective training of sport ball dancers with the help of complex, combined personality oriented psychological influence on the base of dynamic meditation [5].

In this work we show usefulness of dynamic meditation's application in sport ball dances, in case of training of pairs, making mistakes in compositions, owing to bad mastering of figures' sequence, scattering of attention, inability for concentration of attention and anxiety. 
The fact, that sportsmen periodically make mistakes in dances was the reason of creation of such dancers' training methodic, in which barriers of stereotypes would be overcome. The training methodic, permitting to smooth pair's mistake at the account of dancers' adequate responding to them has become urgent.

The work has been fulfilled in compliance with SRW plan of school of higher sportsmanship.

Purpose, tasks of the work, material and methods

The purpose of the research: is to work out methodic of influence on sport ball dancers for their quick responding to mistakes made by them. The trainees shall fulfill other figures instead of envisaged by compositions.

The object of the research: sport ball dancers - seniors' category.

The subject of the research: process of influencing on central nervous system of dancers, who make mistakes, with the help of figures, which are not stipulated by composition.

The tasks of the research:

1.Train dances to dynamic meditation, against the background of which we carried out trainings with intentional including of figures, not envisaged by composition, for working out of timely pair's response to possible mistakes.

2. Determine connection of hypnosis sensitivity with she-partner's ability to adequately respond to changes in dance, admitted by two partners. influence.

The methods of the research: analysis of scientific-methodic literature, pedagogic observation, psychological

Organization of the research: the research was conducted on base of School of higher sportsmanship in Nikolayev. It involved 20 persons, who trained sport ball dances in category "seniors". 10 of them were experimental group and $10-$ control one.

At $1^{\text {st }}$ stage we completed experimental group, considering their sensitivity to hypnosis, to make training of dynamic meditation easier. Sportsmen wit $2^{\text {nd }}$ and $3^{\text {rd }}$ degree of sensitivity to hypnosis were included in experimental group.

At the $2^{\text {nd }}$ stage we trained experimental group to dynamic meditation. For this purpose, first we trained static meditation, then the tested opened eyes and continuing to be in meditation state, practiced dynamic meditation. Mastering of static meditation was carried out with the help of hypnotic suggestion.

At $3^{\text {rd }}$ stage we trained sport ball dances with including new figures, changing sequence of composition. Coach evaluated response of the tested in dance in dynamic meditation.

The worked out by us methodic was realized in two directions:

1. Intentional making of mistakes for working out of reflex of adequate response to them.

2.We analyzed all possible mistakes in dance, determined similarity of figures by first steps and carried out trainings with consideration of possible mistakes.

Example1. All tested of experimental group were immersed in static meditation, in which they danced with opened eyes. It prepared dancers to quick immersion in changed state of consciousness, intrinsic to dynamic meditation.

Example2. Partner Sh. intentionally changed figure "closed change" by figure "wisk" in composition of slow waltz. She-partner S., danced "wisk" obeying to he-partner.

Example 3. Partner O. danced "double left spin" instead of "left turn" of slow waltz, she partner T. made the same.

Example 4. Partner N. danced figure "four step" instead tango figure "closed promenade", she-partner did the same, following her partner.

Example 5. Partner K. Danced "right turn" instead quick-step figure "pivot of right turn"; she partner also danced the same figure.

\section{Results of the researches} meditation.

At 2 nd stage of the research experimental group dancers required from 3 to 7 repetitions for training dynamic

At $3^{\text {rd }}$ stage of the research 8 dancers of experimental group mastered adequate responding to changes in composition after 10-15 trainings.

In control group change of figure by partner during fulfillment of composition resulted in stoppage of dancing pair. dance.

In experimental group, in 8 dancers changes of figures did not render any negative influence on quality of

For older group of dancers it was difficult to learn new figures; they had bad stereotype of movements and they preferred to dance earlier mastered compositions.

Seniors, who did not have sufficient technical arsenal (2 persons) showed low abilities, had bad memory and spent 3 months for mastering of new compositions.

Dancers have failures in execution of compositions, which result in stoppage of pairs. In case of mistake, which change compositional sequence of figures, she-partner shall quickly respond to this change, dancing the same with he-partner figure. This ability is facilitated by dynamic meditation, included in offered by us method against the background of full calmness and absence of neurotic symptoms, for she-partner to adequately respond to he-partner's sudden occasional change of compositional sequence of dance figures. But dynamic meditation can not exclude failures in dance completely because of presence of stereotype movements. 
Mistakes in dances happen often, when composition has not been mastered sufficiently or when attention of hepartner is distracted to foreign objects. The art of she-partner implies timely fulfillment of figure, which is fulfilled by he-partner by mistake. She-partner shall feel her partner sufficiently and follow him so that dancers would feel that they are one, without hindering each other. Such feeling appears owing to many years' trainings.

Specific feature of dynamic meditation is that in martial arts sportsman does not expect some definite action from adversary; he is ready to resist any attack. That is why the best variant for she-partner is to be permanently in state of dynamic meditation As far as figures are danced without pauses; theoretically it is impossible to respond to change of figure, though multiple trainings permit to do it with speed, sufficient to make it invisible for spectator. Indeed, spectator do not see that she-partner fulfills movements with little delaying in order to obey he-partner and not to interrupt contact with him. Also spectator can not notice how additional figure (for better beauty of dance) change rhythm. For example with "spin-right turn" in slow waltz movement is accelerated so that to be a little bit longer at point of maximal raise at count " 2 " in second tact.

Some figures are similar and danced with the same start; exactly this similar part can be the reason of failures of he-partner. For example, figure "chaccet- left turn" is not recommended to be fulfilled after "one-quarter turn", because she-partner can make mistake and start "zigzag".

So, he-partner leads she-partner, making movement with torso; she-partner shall follow he partner with little delay, equal to parts of second. This period is sufficient to re-switch to other figure, in case of he-partner's mistake, if to be in state of dynamic meditation and if elements of figure are not stereotype. But in case of she-partner's mistake, hepartner does not have these parts of second and quality of dance will depend on ability of partner to quickly respond to compositional change. To avoid such situations, she-partner made intentional mistakes at trainings and he-partner, being in dynamic meditation, tries to respond them in due time and make it invisible for spectator

Usually at performance composition is repeated 2-3 times. After successful first fulfillment of composition, he-partner can weaken his attention owing to tiredness or distraction of his attention, hoping that further execution will be successful also. That is why, at trainings it is purposeful to include new figures in composition without agreement with she-partner and realize them in second repetition of the composition.

This method does not describe mistakes in fulfillment of some figures, but says about loss of some figures form compositional sequence.

It should be noted that dynamic meditation is a natural process, which often appears at subconscious level in dance process. But as far as in dances acts reflex mechanism of composition's fixing in stereotypes our methodic with intentional introduction of mistakes develops adequate partners' response for maintenance of quality and aesthetic of dance.

However, excessive introduction of new figures, which do not correspond to initial composition, can result in creation of new stereotype, which will significantly complicate elimination of possible mistakes. This principle has way out: inclusion of new figures only in one and the same place not very often and use them chaotically. Such approach will result in adaptation of she-partner to any mistake of her partner and increase ability to adequately respond to them.

Specific feature of worked out by us method is the fact that in contrast to martial arts, where there is no strict sequence of techniques' fulfillment in ball dances there executed variations and compositions, formed beforehand and they are fulfilled until stereotype of movements is mastered. That is why, is in martial arts, in dynamic meditation sportsman responds to adversary's actions by certain techniques at subconscious level, then dynamic meditation in ball dances is insufficient for she-partner's quick adequate response to he-partner's mistake, because her performance is realized on the base of mastered stereotypes. The only way out is to intentionally introduce he-partner's mistakes at trainings and she-partner should train to quickly respond to them.

After arbitrary change of figure there appears a difficulty in continuation of dance because not all figures match each other. That is why successful continuation of dance will depend on what combination of figures will be used by he-partner. Such combinations of variations shall be composed beforehand.

If to regard martial arts then we see that in fight there is no compositions; all happens spontaneously; there is no stereotype of movements, combinations, composed of different techniques in contrast to dance. It is better if movements are not fixed in stereotypes. For avoiding of stereotypes in combinations of figures it is better to train separate figures but not their combinations. It will resemble dynamic meditation in martial arts.

In experimental group change of figures did not influence on quality of dance, except cases, when we trained dance figures previously with further combining them in compositions without fixing movements in stereotypes. This was because absence of stereotype, in its tuen, increased probability of mistakes.

\section{Conclusions}

The methodic, worked out by us and stipulated introduction of separate dance figures in training process instead of compositions, ensured development of dancers' ability to quickly respond to mistakes, made in dancing.

Mastering of dynamic meditation depended on typological features of nervous system: the higher degree of hypnotic sensitivity was, the better was mastering.

Quick adequate responding to compositional changes, realized by he-partner in dance could be demonstrated by she-partners from experimental group, having high hypnotic sensitivity and practicing dynamic meditation.

Analysis of possible mistakes trains she-partner's ability to timely re-switch from one figure to other.

This method facilitates significant acceleration of improvement of dancers' sportsmanship. 
Further researches will be oriented on determination of the worked out methodic influence on dancers of other age categories.

\section{References}

1. Gagonin S.G. Sportivno-boevye edinoborstva [Sports and martial arts], Sankt Petersburg, SAPC, 1997,352 p.

2. Koroleva E.A. Sovetskaia etnografiia [Soviet ethnography], 1975, vol.5, pp. 147-155.

3. Mur A. Peresmotrennaia tekhnika evropejskikh tancev [Revised European dance technique], Sankt Petersburg, 1993, 48 p.

4. Mur A. Bal'nye tancy [Ballroom dancing], Moscow, Astrel, 2004, 320 p.

5. Omel'ianenko V.I. Pedagogika, psihologia ta mediko-biologicni problemi fizicnogo vihovanna $i$ sportu [Pedagogics, psychology, medical-biological problems of physical training and sports], 2014, vol.1, pp. 46-50. doi:10.6084/m9.Figshare.894390.

6. Omel'ianenko V.I. Pedagogika, psihologia ta mediko-biologicni problemi fizicnogo vihovanna $i$ sportu [Pedagogics, psychology, medical-biological problems of physical training and sports], 2014, vol.2, pp. 42-47. doi:10.6084/m9.figshare.923513

7. Omel'ianenko V.I. Teoriia i praktika fizicheskoj kul'tury [Theory and practice of physical culture], 1990, vol.11, pp. 47-48.

8. Stanislavskij K.S. Akterskij trening [Actor training], Moscow, Astrel, Poligrafizdat, Prime Evroznak, 2010,448 p.

9. Endrius T. Magiia tanca [Magic of dance], Moscow, REFL - book, Kyiv, Wack - Guard rails, 1996, 256 p.

10. Connolly M.K., Quin E., Redding E. dance 4 your life: exploring the health and well-being implications of a contemporary dance intervention for female adolescents. Research in Dance Education 2011, vol.12(1), pp. 53-66. doi:10.1080/14647893.2011.561306.

11. DeMers J.D. Frame matching and $\triangle$ PTED: a framework for teaching Swing and Blues dance partner connection. Research in Dance Education 2013, vol.14(1), pp. 71-80. doi:10.1080/14647893.2012.688943.

12. Kerr C.E., Jones S.R., Wan Q. Effects of mindfulness meditation training on anticipatory alpha modulation in primary somatosensory cortex. Brain Research Bulletin. 2011, vol.85(3-4), pp. 96-103. doi:10.1016/j.brainresbull.2011.03.026.

13. Omelyanenko V.I. Autoand heterosuggestion in boat rowing. Pedagogics, psychology, medical-biological problems of physical training and sports, 2013, vol.12, pp. 53-57. doi:10.6084/m9.figshare.880618

14. Pulinkala J. Integration of a professional dancer into college. Research in Dance Education. 2011, vol. 12 (3), pp. 259-275. doi: 10.1080/14647893.2011.614331.

15. Sood A., Jones D.T. On Mind Wandering, Attention, Brain Networks, and Meditation. EXPLORE: The Journal of Science and Healing. 2013, vol.9(3), pp. 136-141. doi:10.1016/j.explore.2013.02.005. 


\section{Information about the author:}

Omelyanenko V. I.: ORCID: http://orcid.org/0000-0001-7927-3842 hrebenik@ukr.net; Mykolaiv Higher Sportsmanship School; Ingul descent, 4, Mykolaiv, 54001, Ukraine.

Cite this article as: Omelyanenko VI Complex integrated method of improvement of sports ballroom dance performance. Physical education of students, 2014, vol.6, pp. 49-53. doi: $10.15561 / 20755279.2014 .0610$

The electronic version of this article is the complete one and can be found online at: http://www.sportpedu.org.ua/html/arhive-e.html

This is an Open Access article distributed under the terms of the Creative Commons Attribution License, which permits unrestricted use, distribution, and reproduction in any medium, provided the original work is properly cited (http:// creativecommons.org/licenses/by/3.0/deed.en).

Received: 25.056 .2014

Published: 30.06 .2014 